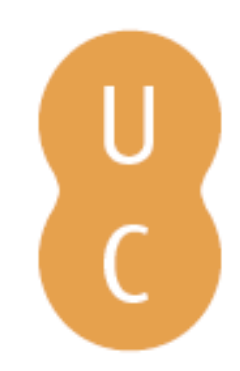

\title{
nombalina
}

\section{Freshwater macroinvertebrates in the Mondego river basin}

Autor(es): $\quad$ Graça, Manuel Augusto; Coimbra, Nuno; Carvalho, Maria João; Oliveira, Ricardo; Abelho, Manuela

Publicado por: Imprensa da Universidade de Coimbra

URL

persistente: URI:http://hdl.handle.net/10316.2/32661

DOI: $\quad$ DOI:http://dx.doi.org/10.14195/978-989-26-0336-0_7

Accessed : $\quad$ 26-Apr-2023 06:48:49

A navegação consulta e descarregamento dos títulos inseridos nas Bibliotecas Digitais UC Digitalis, UC Pombalina e UC Impactum, pressupõem a aceitação plena e sem reservas dos Termos e Condições de Uso destas Bibliotecas Digitais, disponíveis em https://digitalis.uc.pt/pt-pt/termos.

Conforme exposto nos referidos Termos e Condições de Uso, o descarregamento de títulos de acesso restrito requer uma licença válida de autorização devendo o utilizador aceder ao(s) documento(s) a partir de um endereço de IP da instituição detentora da supramencionada licença.

Ao utilizador é apenas permitido o descarregamento para uso pessoal, pelo que o emprego do(s) título(s) descarregado(s) para outro fim, designadamente comercial, carece de autorização do respetivo autor ou editor da obra.

Na medida em que todas as obras da UC Digitalis se encontram protegidas pelo Código do Direito de Autor e Direitos Conexos e demais legislação aplicável, toda a cópia, parcial ou total, deste documento, nos casos em que é legalmente admitida, deverá conter ou fazer-se acompanhar por este aviso.

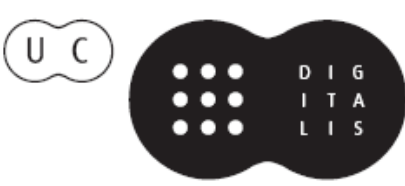


MIGUEL ÂNGELO PARDAL JOÄO CARLOS MARQUES MANUEL AUGUSTO GRAÇA Scientific Editors

\section{Aquatic Ecology of the Mondego River Basin Global Importance of Local Experience}




\author{
MIGUEL ÂNGELO PARDAL \\ JOẢO CARLOS MARQUES \\ MANUEL AUGUSTO GRAÇA \\ Scientific Editors
}

\title{
Aquatic Ecology of the Mondego River Basin Global Importance of Local Experience
}




COORDENAÇÃO EDITORIAL
Imprensa da Universidade de Coimbra
CONCEPÇÃO GRAFICA
António Barros
INFOGRAFIA
António Resende
Estimulus [design] • Coimbra
EXECUÇÃO GRAFICA
GRAFIASA
ILUSTRAÇÃO DA CAPA
P. P. Cunha e ]. Dinis
ISBN
972-8704-04-6
DEPOSITO LEGAL
I75038/02

(C) JANEIRO 2002, IMPRENSA DA UnIVERSIDADE DE COIMBRA

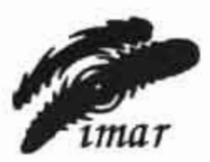

CPIMAR

imar

OBRA PUBLICADA COM O PATROCINIO DE:

IMAR - INSTITUTO DO MAR

IPIMAR - INSTITUTO DE INVESTIGAÇĀO DAS PESCAS E DO MAR 



\author{
Manuel Augusto Graça \\ NUNO COIMBRA ' \\ Maria joảo CarvalHo ' \\ RICARDO OUIVEIRA ' \\ Manuela AbelHo 1,2
}

\title{
FRESHWATER MACROINVERTEBRATES INTHE MONDEGO RIVER BASIN
}

\begin{abstract}
Invertebrates in streams and rivers are diverse, abundant and perform important ecological functions, recycling organic matter, feeding upon aigae and transferring energy for larger animals, including fish, birds, amphibians and others. The macroinvertebrate communities of 34 stream sites in the Mondego River basin were analysed to assess changes in taxa richness and percentage of shredders along river order / size gradient and to assess water quality by means of biotic indices. Taxa richness was higher in low order streams when compared with larger rivers. In some rivers, shredder abundance was higher in autumn, but in other rivers we did not observe changes in shredder abundance along the year. Water quality, measured by the application of the biotic index BMWP', revealed that many small low order streams can be considered as unpolluted. However, water quality decreased in larger rivers.
\end{abstract}

\section{Introduction}

In stream ecology studies, the definition of macroinvertebrates is subjective: invertebrates visible to the naked eye. In more practical terms, they are invertebrates captured by a 0.2 to $0.5 \mathrm{~mm}$ sampling net (Hellawell 1978). Unlike in salt-water systems and soil, freshwater macroinvertebrates are uniform in size, with most of specimens ranging from fractions of $\mathrm{mm}$ to $30 \mathrm{~mm}$.' In streams and rivers, macroinvertebrates comprise mostly insects, but also include other arthropods (Acarina, Crustacea), worms and leaches (Annelida), flatworms (Plathelminthes), nematodes (Nematheiminthes), snails and bivalves (Mollusca) (Tachet et al. 1987). Among the insects, 4 orders have juvenile stages exclusively aquatic and adults with aerial life: Ephemeroptera, Plecoptera, Odonata and Trichoptera. Some Diptera also have a juvenile aquatic phase. Two additional orders may be abundant in the water either as juveniles and / or adults: Heteroptera and Coleoptera.

\footnotetext{
in IMAR - Instituto do Mar, Centro Interdisciplinar de Coimbra, aic Departamento de Zoologia, Universidade de Coimbra, 3004-517 Coimbra, Portugai

as Escola Superior Agrária. Instituto Politécnico de Coimbra. Bencarta, 3040-316 Coimbra. Portugal
} 
Vannote et al. proposed in 1980 a general model - the River Continuum Concept ( $R C C$ ) - to explain the functional link along rivers, from the source to the mouth. This framework establishes the relationships between stream order / size and energy sources of rivers. According to the RCC, streams receive most of their energy in the form of leaves and other plant detritus produced in the riparian area. This material will be used as food by a large proportion of aquatic macroinvertebrates. Macroinvertebrates are, in tum, the energy source for many species of fish, amphibians and aquatic birds and mammals.

Freshwater macroinvertebrates have been used for nearly a century as indicators of water quality (e.g. Kolkwitz and Marsson 1908, 1909). The reason is simple: It has been documented for long time that as the quality of water deteriorates, an increasing number of species no longer are capable of survive and the diversity of the community generally decreases. The first taxa to disappear are known as "intolerant". With the elimination of competitors and predators, the remaining species tend generally to grow to large numbers, especially if the food is abundant. These organisms are known as "tolerant". Decrease in water quality may therefore result in a decrease in diversity and change community structure and function.

Changes in (a) diversity of macroinvertebrates, (b) the structure of the community and $(c)$ the proportion of taxa with known environmental tolerances have been therefore used as indicators of environmental quality in biomonitoring programmes (Metcalfe-Smith 1996). Biotic indices have also been used to assess water quality. Those indices are numerical expressions based on the presence and number of indicator taxa. Biotic indices have been used in Europe and North America for several decades for routine rapid assessment of water quality in rivers (e.g. De Pauw and Vanhooren 1983. Washington 1984, Metcalfe 1989).

Although several groups of taxa can be used for biomonitoring proposes (e.g. algae, macrophytes, bacteria, fish, protozoans), macroinvertebrates are the most popular. Three main reasons contribute to such popularity: (a) They have low mobility or are fixed to the substratum and, therefore, their composition is related to water conditions at the place where they occur. (b) Most taxa are ubiquitous; this is very convenient when trying to make comparisons among different areas. (c) There is a high diversity of forms, colonizing almost any environmental condition (Hellawell 1978).

In Portugal several research groups have been studying the distribution or the ecology of freshwater invertebrates. E.g. Fontoura (1984), Fontoura and De Pauw 116 (1989) in Northern Atlantic rivers: Cortes $(1990,1992)$ in the Northeast; Moreira et al. (1988) in the Vouga Basin; Graça et al. (1989), Abelho and Graça (1996) in the Central Portugal and Graça and Coimbra (1998), Coimbra and Graça (1998), Graça et al. (1995), Coimbra et al. (1996), Malo et al. (1998) in the South.

The objective of this paper was to summarise the research carried in the Mondego River basin in terms of (a) richness of taxonomic invertebrate groups along a longitudinal gradient (b) proportion of shredders along river order gradients, and (c) classification of water quality by means of macroinvertebrate indicators. For this propose, we used published and unpublished data. 


\section{Materials and methods}

We used data originally from Graça et al. (1989. R. Alva and R Soure). Abelho and Graça (1996; rivers from Açor and Margaraça Mountains), Graça et al. (200I; Lousã mountain and Ceira basin). We also used unpublished material collected by (a) Carvalho and Coimbra in several rivers at the Lousã and Caramulo Mountains, and (b) Oliveira and Coimbra at the upper Mondego River and several tributaries.

Samples of invertebrates were generally collected with a hand net $0.3 \times 0.3$ aperture and $0.5 \mathrm{~mm}$ mesh size. When rigorous quantitative sampling was necessary (and possible) Surber samples were collected (same dimensions as hand net). At each sampling site, in general, six sample replicates were collected at the major macrohabitats, covering each a distance of approximately I meter. Samples were transported to the laboratory and the specimens sorted alive. Alternatively, samples were preserved in the field with $4 \%$ formalin, and the invertebrates sorted after washing with tap running water. For preservation we used $70 \%$ ethanol. Identification was done to the level of species (e.g. some Plecoptera) or, more frequently to genus (e.g., Coleoptera), but in many cases specimens were only identified to family (e.g. Diptera) or to sub-family (e.g. Chironomidae) levels.

Invertebrate sampling was generally accompanied of water sampling for chemical analysis. Several physical parameters of streams and rivers were also measured. In order to understand the distribution of macroinvertebrate taxa, a table was produced relating the 3 more abundant taxa with the environmental stream characteristics. For each biological sample, the proportion of shredders (i.e. invertebrates feeding on decaying leaves) was computed, related with the stream order and compared with the previsions of the river continuum model. Finally, for each invertebrate collection, a biotic index was computed: the BMWP' adapted for the Iberian Peninsula ( Alba-Tercedor 1996. AlbaTercedor and Sanchéz-Ortega 1988) in order document water quality.

\section{Results}

We analysed more than 30 stream sites sampled once to four times. Most of the sites corresponded to low order ( $\leq 4)$, narrow rivers (width $<5$ m; Table I). In terms of discharge and width, the larger rivers were Alva, Soure and Ceira. In general, those were also the rivers with higher water velocities. The Mondego River was not sampled in a correspondent larger section. All rivers had high content of dissolved oxygen, probably as a result of the continuous flow and/or lack of strong organic load. However. in terms of water chemistry, there was a high variation with $\mathrm{pH}$ values ranging from acidic $(\mathrm{pH}<5)$ to basic $(\mathrm{pH}>8)$ and conductivity ranging from $<30 \mu \mathrm{S}$ to $>300 \mu \mathrm{S}$ (Table 2). Nutrient content was generally low, except in some sites were the higher values denote organic pollution (Table 2).

In general, the number of invertebrate families was low in larger rivers, when compared with streams of low to intermediate order ( $\leq 5$; Table 3 ). As an example, along a longitudinal transept, the maximum number of invertebrate families sampled in 


$$
=
$$

Table I. Selected physical characieristics of the studied stram / mver sites. Subst= mean size of the dominant substrate particles

\begin{tabular}{|c|c|c|c|c|c|c|c|c|}
\hline Stream / Ruver & $\begin{array}{l}\text { Subst } \\
(\mathrm{cm})\end{array}$ & $\begin{array}{l}\text { Width } \\
\text { (m) }\end{array}$ & $\begin{array}{l}\text { Depth } \\
\text { (m) }\end{array}$ & $\begin{array}{l}\text { Current } \\
\left(m s^{-1}\right)\end{array}$ & $\begin{array}{l}\text { Flow } \\
\left(\mathrm{m}^{3} \mathrm{~s}^{\prime \prime} \times 10^{3}\right)\end{array}$ & $\begin{array}{l}\text { Ternp. } \\
\left({ }^{\circ} \mathrm{C}\right)\end{array}$ & $\begin{array}{l}\text { O: } \\
m g L^{\prime \prime}\end{array}$ & Source \\
\hline 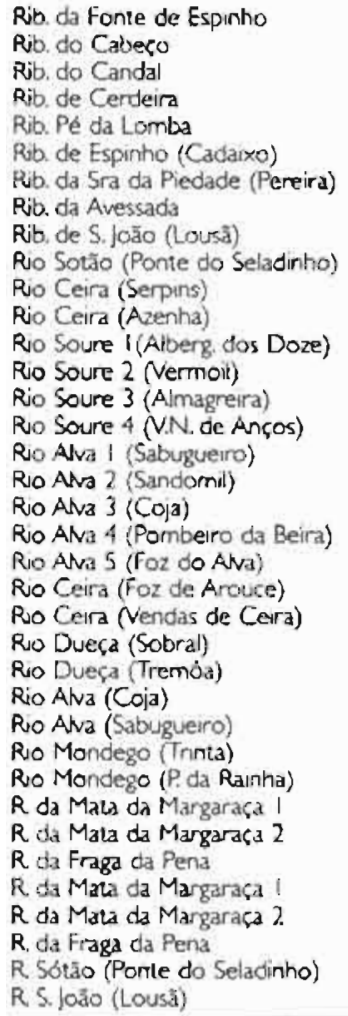 & $\begin{array}{l}19 \\
16 \\
17 \\
21 \\
>30 \\
12 \\
16 \\
8 \\
10 \\
>30 \\
18 \\
14 \\
5 \\
15 \\
10 \\
41 \\
730 \\
10 \\
9 \\
2 \\
<1 \\
7 \\
8 \\
5 \\
5 \\
8 \\
19 \\
13 \\
7 \\
6 \\
6 \\
7 \\
6 \\
6 \\
7-8 \\
9.10\end{array}$ & $\begin{array}{l}0.4 \cdot 17 \\
0.5 \cdot 1.1 \\
1.3 \cdot 1.6 \\
0.6-0.6 \\
0.3-0.7 \\
21 \cdot 2.2 \\
0.9 \cdot 2.3 \\
12-1.2 \\
1.5 \cdot 6.8 \\
0.7-11.1 \\
17 \\
125 \cdot 11.7 \\
2 \\
7 \\
9 \\
15 \\
5 \\
13 \\
15 \\
14 \\
28 \\
- \\
- \\
: \\
- \\
- \\
5 \\
- \\
5 \\
- \\
- \\
5 \\
5 \\
- \\
6.9 \\
5.8 \\
\end{array}$ & $\begin{array}{l}0.1-0.2 \\
0.1 \\
0.1 \\
0.2 \\
0.1-0.2 \\
0.1 \\
0.1-0.3 \\
0.1 \\
0.2-0.1 \\
0.3-0.4 \\
0.2 \\
0.2-0.3 \\
0.3 \\
0.3 \\
0.3 \\
0.7 \\
0.2-0.5 \\
0.3-0.9 \\
0.6-1.1 \\
0.8-1.0 \\
0.5-1.6 \\
0.3 \\
0.4 \\
0.3 \\
0.4 \\
0.5 \\
0.5 \\
0.4 \\
- \\
. \\
- \\
- \\
- \\
- \\
- \\
0.2 \cdot 0.4 \\
0.2 \cdot 0.4\end{array}$ & $\begin{array}{l}0.13-0.22 \\
0.10-0.17 \\
0.27-0.29 \\
0.49-0.46 \\
0.10-0.11 \\
0.39-0.41 \\
0.13-0.45 \\
0.31-0.55 \\
0.07-0.22 \\
0.07-0.46 \\
0.38 \\
0.70-0.79 \\
0.46 \\
0.25 \\
0.80 \\
0.49 \\
0.30-1.60 \\
0.20-1.05 \\
0.40 .1 .40 \\
0.10-0.50 \\
0.90-1.20 \\
1.00 \\
0.60 \\
0.43 \\
0.80 \\
0.22 \\
0.14 \\
0.34 \\
0.024-0.62 \\
0.15-0.32 \\
0.10-0.67 \\
0.24-0.62 \\
0.15-0.32 \\
010-0.67 \\
0.11 \cdot 0.34 \\
0.01-0.10\end{array}$ & $\begin{array}{l}9-49 \\
9.11 \\
48-52 \\
38-58 \\
3-16 \\
94-114 \\
59-75 \\
39.40 \\
58-200 \\
94-295 \\
1058 \\
1888-2773 \\
290 \\
380 \\
1780 \\
4730 \\
100-5200 \\
500-12300 \\
3600.20600 \\
1000-7500 \\
16200-27400 \\
- \\
. \\
5 \\
- \\
- \\
- \\
- \\
5-15 \\
4-28 \\
21.71 \\
5-15 \\
4-28 \\
21-71 \\
346-392 \\
24-91 \\
\end{array}$ & $\begin{array}{l}8.13 \\
8.13 \\
8.14 \\
8.15 \\
9.15 \\
11.18 \\
10.18 \\
11.18 \\
9.17 \\
9.18 \\
10 \\
10.23 \\
14.16 \\
16.22 \\
6.25 \\
17.27 \\
9-12 \\
1.14 \\
3.21 \\
4.26 \\
4-27 \\
165 \\
15.9 \\
16.0 \\
15.8 \\
5.2 \\
6.8 \\
4.6 \\
7.6 \\
10.013 .6 \\
90.14 .2 \\
10.0-16.0 \\
10.0-13.6 \\
9.0-14.2 \\
10.0 .160 \\
13.6 .14 .1 \\
14.2 \cdot 15.7\end{array}$ & $\begin{array}{l}9.3-95 \\
9.5-9.6 \\
9.5-9.6 \\
9.4-9.5 \\
9.5-9.7 \\
10.1 \\
10.2-10.5 \\
95-9.8 \\
9.9-10.2 \\
9.8-10.2 \\
10.5 \\
9.4-10.8 \\
9.4-11.3 \\
9.3-11.9 \\
9.8-10.1 \\
9.6-10.0 \\
8.5-11.4 \\
8.6-12.4 \\
8.8 \cdot 12.4 \\
9.0 .12 .2 \\
9.1-12.3 \\
79 \\
7.4 \\
8.6 \\
77 \\
9.9 \\
105 \\
11.5 \\
9.4 \\
10.4-14.1 \\
10.3 \cdot 17.1 \\
10.2-16.3 \\
10.4-14.1 \\
10.3-17.1 \\
10.2 \cdot 16.3 \\
10.8-11.0 \\
9.6-9.8\end{array}$ & 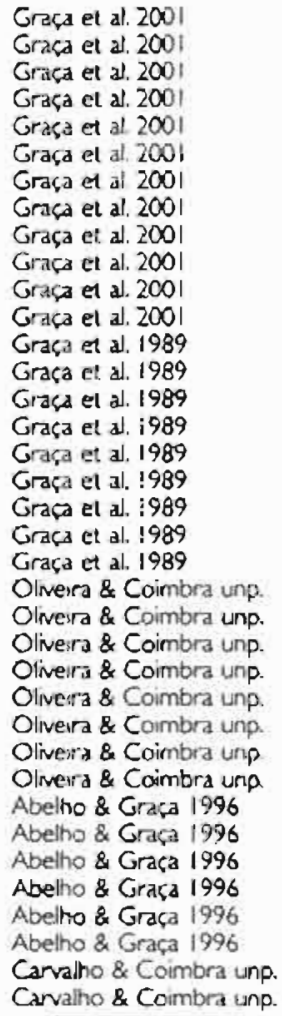 \\
\hline
\end{tabular}


Table 2. Waier chemistry of the studied stream / nver snes.

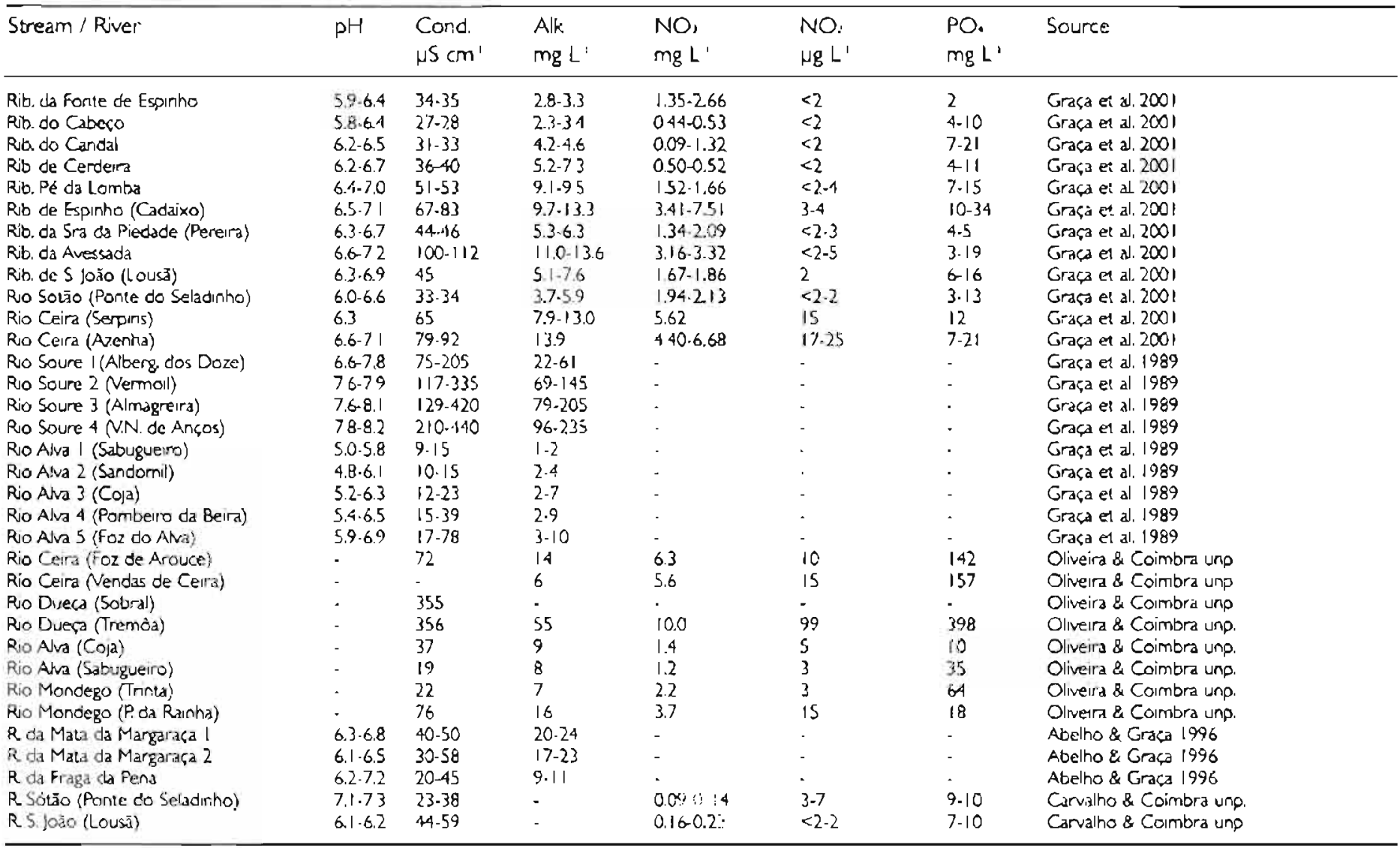


the Alva River decreased from 27 in the uppermost site to 21,18 , and 16 just before the confluence with the Mondego. Low number of families were also observed in the Ceira $(8-11)$ and in the Mondego itself $(18-19)$. when compared with low order streams (generally $>20$ taxa; Table 3 ).

In low order streams, shredders were the dominant feeding group in terms of percentage of taxa or percentage of total invertebrate AFDM (Tables 4 and 5). The importance of shredders tended to decrease downstream. Patterns of seasonal (summer vs. winter) variation of shredders differed among rivers. In the Lousã streams, the variation was low. However, in the Alva River the shredder taxa varied from $0 \%$ to $37 \%$ (Graça et al. 1989). The longitudinal and seasonal variation in shredders was in agreement with the River Continuum (Vannote et al. 1980).

In terms of water quality, as judged by the application of the biotic index BMWP', the rivers and streams from the Lousã mountain can be considered unpolluted (Table 3). Scores above 200 were recorded at ribeira do Espinho (Cadaixo) and Ribeira da Sra da Piedade (Pereira). According to data from 1989, the Soure River had an intermediate situation. In some cases it revealed clean conditions, whereas in other occasions it revealed pollution stress. At Soure 4 (V.N. Anços) the low score of the index revealed a clear pollution stress. The situation was similar for the Alva River However, the lower Alva River had a predominance of a sandy substrate and it has frequently demonstrated that this substrate is unfavourable for invertebrate colonisation and therefore, the low score could reflect, in this case, not only a decrease in water quality, but also the substrate characteristics.

Water quality in the Ceira nvers varied from good - acceptable (BMWP' $=122$ 152) to bad (BMWP' $=48$ and 75). The same occurred in the Mondego River (BMWP' $=89.114)$. In general, in the Mondego River there are streams with a clear high quality of waters and severely polluted sites.

\section{Discussion}

Higher taxa richness was observed in low order streams $(\leq 4)$ when compared with intermediate / larger rivers $(\geq 5)$ ). This pattern was postulated by the river continuum concept (Vannote et al. 1980), based on the spatial and temporal environmental heterogeneity of intermediate rivers. Although we measured richness in terms of number of families, some studies have shown a strong correlation between the number of species and the number of higher taxonomic groups (e.g. Graça et al. 1995, Chessman 1995).

As predicted by the river continuum concept, shredders were the dominant group in the low order streams but decreased downstream. This can be explained by the expected differences in the amount of coarse particulate organic matter. However, the differences in seasonal changes are more challenging. Although litter inputs are higher in autumn than in other seasons (Abelho and Graça 1998), organic matter accumulation in the stream bed may not be correlated with litterfall due the hydrologic regime and the occurrence of spates causing an increased transport of benthic organic 
Table 3. Brological parameters and water quality according with the BMWP' index for several stream / nver stes in the Mondego nver basin.

\begin{tabular}{|c|c|c|c|c|c|c|}
\hline Stream / River & Order & $N^{\circ}$ Families & BMW'P' & Year & Representative Farnilies & Source \\
\hline Rib da Fonte de Esoinho & 2 & $14-23$ & $112-160$ & $1998 / 1999$ & Leucundae. Nemouridae. Orironomidae & Graça en al. 2001 \\
\hline Rib do Cabeso & 2 & 18.26 & 125.159 & $1598 / 1999$ & Leucondae. Chironomidae. Nemoundae & Graca et al 200 \\
\hline Rib. do Candal & 3 & $27-28$ & $181-185$ & $1998 / 1999$ & Leucundae. Goendae, Chironomidae & Graça et al. 2001 \\
\hline Rib. de Cerderra & 3 & 27.35 & 168.237 & $1998 / 1999$ & Leucundae. Gironamidae, Hydropsyciudae & Graca et al. 200 \\
\hline Rib. Pé da Lomba & 3 & 19.27 & 109.175 & $1998 / 1999$ & Chironomidae. Sphaendae. Sericostomat: Cde & Graça et al. 200 \\
\hline Rib. de Espinho (Cadaroo) & 4 & 30.33 & 229.240 & 19981999 & Chironomidae, Sphaen dae. Lumnephilidae & Graca et al, 2001 \\
\hline Rub. da Sra da Piedade (Pererra) & 4 & 34.42 & $210-270$ & $1998 / 1999$ & Baevdae, Emidae. Tricladida & Graça ct al. 200 \\
\hline Rib.da Aversada & 4 & $33-34$ & 188.212 & $1998 / 1999$ & Chironomidae, Baetidae, Limnephisidae & Graça et al. 200। \\
\hline Rib. de S. Joāo (Lousā) & 5 & $2 \%-29$ & $166-181$ & $1998 / 1999$ & Chironomidae, Hydropsychidae. Leuctridae & Graça et al. 200 \\
\hline Ro Sotäo (Ponte do Seladinho) & 5 & $30-33$ & $180-242$ & $1998 / 1999$ & Baetıdae. Chironomidae, Leuctrdae & Graça et al. 200! \\
\hline Rio Ceira (Serpins) & 6 & 24 & 152 & $1998 / 1999$ & Baevidae. Simulidae, Philopotamidae & Grapa et al. 2001 \\
\hline Ro Celra (Azenha) & 6 & 21.22 & $122 \cdot 127$ & $1998 / 1999$ & Hydropsychidae, Philopotamidae, Baretidae & Graça et al. 200 \\
\hline Ro Soure I (Abberg dos Doze) & . & 14.22 & $80-108$ & $1984 / 1985$ & Polomopirgus, Boelus. Coenis & Graça et al 1989 \\
\hline Ro Soure 2 (Nenmoil) & . & 18.25 & 88.159 & 198411985 & Polomopyrgus. Chironomidae. Boeus & Graça et al 1989 \\
\hline Rio Soure 3 (Almagneira) & . & $15-24$ & 61.101 & $1984 / 1985$ & Simuliidae, Bcetss, Chironomidae & Graça ex al. 1989 \\
\hline Ro Soure 4 (V.N. de Ansos) & - & 8.18 & $35-82$ & $1984 / 1985$ & Chironomidae. Hydracanna Simulidae & Graça et al 1989 \\
\hline Ruo ANá I (Sabuguerro) & . & 15.27 & $93-150$ & $1984 / 1985$ & Levera Amphinemura, Hyoropsyche & Grasa et al 1989 \\
\hline Ro Alva 4 (Pombeiro da Beira) & - & $12-18$ & $75-96$ & $1984 / 1985$ & Caenis. Boetrs. Chironomidae & Graça et al 1989 \\
\hline ROA Ava S (FOZ do ANva) & - & 7.16 & 37.98 & $1984 / 1985$ & Baeus, Choroterpes. Simulidae & Graça et di. 1989 \\
\hline Wo Cera (Foz de Arouce) & - & 15 & 75 & 1999 & Boeus, Polomopyngus, Chimarra & Olveira \& Coimbra unp \\
\hline Rio Ceira (Vendas de Cerra) & . & 8 & 48 & 1999 & Lumbriculidae, Hydropsyche. Boyerio & Oiveira \& Combra unp. \\
\hline Rio Duera (Sobral) & - & II & 51 & 1999 & Boevs, Aryuephyro, Simuliidac & Olveira \& Coimbra ung. \\
\hline Rio Dueca (Tremóa) & . & 15 & 60 & 1999 & Athycephymi, : umbriculidae, Coenus & Olmeira \& Coimbra unp. \\
\hline Ro Alva (Coja) & - & 9 & 48 & 1999 & Ephemerella, Boets. Nemoura & Olnuera \& Coimbra unp. \\
\hline Rio Alva (Sabuguerro) & . & 14 & 81 & 1999 & Leuaro, Boets, Lmnephilidae & Olverra \& Coimbra unp \\
\hline Rio Mondego (Trinta) & . & 19 & 114 & 1999 & Sumuliidae, Sencostoma. Baeis & Oliveira \& Colmbra ung. \\
\hline Roo Mondego ( $\mathrm{Pda}$ Rainha) & - & 18 & 89 & 1999 & Chironomidae, Coen's, Boeus & Oliveira \& Combra unp. \\
\hline R da Mata da Margaraça I & $!$ & 32.35 & 187.198 & $1991 / 1992$ & Chironomidae, Leuctro, Nadidae & Abeitho \& Graça $1996^{\circ}$ \\
\hline R da Maca da Margaraca 2 & 3 & 31.34 & 201.216 & $1991 / 1992$ & Leuctro Chironomidae, Baetis & Abetho \& Graça $: 996$ \\
\hline R da Frage da Pena & 3 & 28.29 & $181-187$ & $1991 / 1992$ & Leuaro. Chironomidae, Ephemerella & Abeiho \& Graça 1996 \\
\hline R. Sólảo (Ponte do Seladinho) & 5 & $31-36$ & $208 \cdot 225$ & 1996 & Chironornidae. Boeus. Coenls & Carualho \& Combra una \\
\hline R.5 Jojo (Lousä) & 5 & 39.48 & 242.294 & 1996 & Chironomidae, Boetis, Leuetro & Carvalho \& Coimbra unp. \\
\hline
\end{tabular}


Table 4 - Percentage of taxa classified as shredders in several studied sites of the Mondego basin

\begin{tabular}{|c|c|c|c|}
\hline Name & Order & $\begin{array}{l}\% \text { of shredder } \\
\text { taxa }\end{array}$ & Source \\
\hline Rio Soure 2 (Vermoil) & & $0-3$ & Graça et al. 1989 \\
\hline Rio Soure 3 (Almagreira) & & 0 & Graça et al. 1989 \\
\hline Rio Soure 4 ( $V . N$. de Anços) & & $0-1$ & Graça et al. 1989 \\
\hline Rio Alva I (Sabugueiro) & & $9-33$ & Graça et al, 1989 \\
\hline Rio Alva 2 (Sandomil) & & 2.35 & Graça et al 1989 \\
\hline Rio Alva 3 (Coja) & & 0.37 & Graça et al 1989 \\
\hline Ruo Alva 4 (Pombeiro da Beira) & & 1.21 & Graça et al 1989 \\
\hline Rjo Alva 5 (Foz do Alva) & & $0-20$ & Graça et al 1989 \\
\hline Rio Cerra (Foz de Arouce) & & 15 & Olverra \& Coimbra unp. \\
\hline Rio Ceira (Vendas de Ceira) & & 8 & Oliveira \& Coimbra unp. \\
\hline Rio Dueça (Sobral) & & 11 & Olivera \& Coimbra unp. \\
\hline Rio Dueça (Tremôa) & & 15 & Olivera \& Coimbra unp. \\
\hline Rio Alva (Coja) & & 9 & Olverra \& Coimbra unp. \\
\hline Rio Alva (Sabugueiro) & & 14 & Oliveira \& Coimbra unp. \\
\hline Rio Mondego (Trinta) & & 19 & Oitverra \& Coimbra unp. \\
\hline Rio Mondego (P. da Rainha) & & 18 & Oliverra \& Coimbra unp. \\
\hline R da Mata da Margaraça I & 1 & $8-55$ & Abelho \& Graça 1996 \\
\hline R da Mata da Margaraça 2 & 3 & $19-35$ & Abelho \& Graça 1996 \\
\hline$R$ da Fraga da Pena & 3 & $28-37$ & Abelho \& Graça 1996 \\
\hline R Sótāo (Ponte do Seladinho) & 5 & $4-5$ & Carvalho \& Coimbra unp. \\
\hline R S. João (Lousā) & 5 & $6-9$ & Carvalho \& Combra unp. \\
\hline
\end{tabular}

Table 5. Percentage of shredders in terms of biomass $\mathrm{m}^{-4}$ at 12 sites ranging from $2^{\text {se }}$ to $6^{\text {m }}$ order (Lousã region) (after Graça et al. 200I)

\begin{tabular}{ccc}
\hline $\begin{array}{c}\text { Stream } \\
\text { order }\end{array}$ & $\begin{array}{c}\text { Shredder densty } \\
\text { (Hg AFDM m } \mathrm{m}^{\text {) }} \text { ) }\end{array}$ & $\begin{array}{c}\text { \% AFDM of } \\
\text { shredder taxa }\end{array}$ \\
\hline 2 & 65 & 45 \\
3 & 138 & $41-44$ \\
4 & 92 & $20-21$ \\
5 & 17 & $21-24$ \\
6 & 8 & 2 \\
\hline
\end{tabular}

matter (Abelho and Graça 1998). Streams and rivers may differ in their retentiveness and hydrologic regime and these differences may condition the seasonal abundance of shredders. This relationship was not yet tested in our stream systems.

122 Some streams and small rivers had a high water quality, according to the application of biotic index. The BMWP' was adapted for the Iberian Peninsula, but based in studies carried out in Spain. Indices developed for a particular area have been applied, apparently with success, in other geographical areas (e.g. the BBI, developed for Belgium, applied in Portugal, Indonesia, Canada and other areas: Fontoura and Moura 1984, Krystiano and Kusjantono 1991. Barton and Metcalfe-Smith 1992, De Pauw et al. 1986). However, before the application of the indices developed for other areas, it is necessary first to test them according with the local ecological. hydrologic and geological conditions (e.g. Coimbra and Graça 1998. Graça and Coimbra 1998). The 
results of the application of the BMWP' were consistent with the chemical information of the studied sites and therefore, the index is likely to be a useful tool for the water quality assessment in Central Portugal.

For rapid biological monitoring proposals, several studies have shown that aquatic invertebrates identified to the family level are good indicators of water quality. (Graça et al. 1995) showed that reducing the identification of invertebrates to the family level instead of species / genus level saved $50 \%$ of identification effort with no information loss in terms of water quality. The BMWP score system used to evaluate water quality in British rivers (Armitage et al. 1983) rely on families of aquatic invertebrates. Hughes (1978) showed that the diversity $\left(H^{\prime}\right)$ of species, genus, family and orders where highly correlate. Osborne et al. (1980) analysing macroinvertebrate samples identified to species, genus and family levels from contaminated and clean sites showed that identification to family level was sufficed to detect inter-site diversity differences.

Invertebrates in streams and rivers fill numerous ecological niches, feed on aquatic producers and on allochthonous organic matter and serve as food to other aquatic and terrestrial / flying organisms. They are therefore an important energetic component transferring energy and material from the producers and the detritus pool to upper levels in the food chains. Aquatic invertebrates have also been used to test numerous ecological theories (e.g. Allan 1984).

The information here provided resulted from several independent and small-scale investigations. We suggest that macroinvertebrates and environmental conditions of a larger set of clean sampling sites should be investigated in order to provide reference conditions to which impacted or potentially impacted areas could be compared for the propose of water quality evaluation.

\section{References}

Abehe. M. and Graça, MA.5. 1996. Effects of eucalyptus afforestation on leaf litter dynamics and macroinvertebrate community structure of streams in Central Portugal. Hydrobiologia 324: 195-204

Abelho, M. and Graça, M.A.S. 1998. Litter in a first-order stream of a temperate deciduous forest (Margaraça Forest, Central Portugal) Hydrobiologia 386:147.152

Alba-Tercedor.). 1996. Macroinvertebrados acuaticos y calidad de las aguas de los roos. N SIAGA, Almeria. It: 203-213.

Alba-Tercedor.J, and Sanchéz-Ortega, A. 1988. Un método rápido y simple para evaluar la calidad biológıca de las aguas cornentes basado en el de Heliawell (1978). Limnetica 4:51-56.

Allan, JD 1984. Hypothests testing in ecoiogical studies of aquatic insects. in The ecology of aquatic insects. Edited by V.H.Resh and D.M.Rosenberg, pp. 484.507.

Armitage.P.oss, D. Wright, IF. and Furse. MT 1983. The performance of a new brological water quality score system based on macroinvertebrates over a wide range of unpolluted nunning waters. Water Res. 17 . 333-347.

Barton, D.R, and Metcalfe-Smith, H.L. 1992 A comparison of sampling technics and summary indices for assessment of water quality in the-Yamaska River. Québec, based on benthic macronvertebrates. Environ., Monit. and Assess. 21:225-244.

Chessman. B.C. 1995. Rapid assessernent of rivers using macroinvertebrates: A procedure based on habrtatspecific sampling, family level identification and a biotic index. Aust \& Ecol. 20. 122-129

Coimbra. C.N. and Graça, MA.S. 1998. Water quality assessment based on macroinvertebrate community structure: a comparison between methods. Verh. Internat. Verein. Limnol. 26: 2362-2366 
Coimbra. C.N. Graça, MA.S. and Cortes, R.M. 1996. The effects of a basic effluent on macroinvertebrate community structure in a temporary Mediterranean mer. Environ. Pollut. 94: 301-307.

Cortes. RM.V. 1990. Resistence and resilience of streams with low salt content to organic and mine contamination. Envionmental Contamination: 4th International Conference, Barcelona.

Cortes, RM, V, 1992. Seasonal pattern of benthic communities along the longitudinal axis of river systems and the influence of abiotic factors on the spatial structure of those communities. Arch. Hydrobiol. 126: 85103.

De Pauw, N. \& Vanhooren, G. 1983. Method for biological quality assessment of watercourses in Belgium. Hydrobiologia. 100: 153-168.

De Pauw, N. Roels, D., and Fontoura, P. 1986. Use of artificial substrates for standardized sampling of invertebrates in the assessment of water quality by the Belgian Biotic Index Hydrobiologia 133: 237. 258.

Fontoura, A.P. 1984. Les communautés de macro-invertebrés du bassin hydrographique du fleuve Lima comme indicateurs de la qualité biologique de leau. Publ. Inst. Zool. Fac. Ciên. Porto I B3: I-20

Fontoura. A. P. and De Pauw. N. 1989. Macroinvertebrate community structure and impact assessment of dams in the Cóvado River Basin (Northern Portugal). 24th SIL Congress.

Fontoura. A.P. and Moura, A.M. 1984. Effects of some industrial effluents in the biological quality of the water of river Lima. Publ. Inst. Zool. Fac. Ciên. Porto 184: I-21.

Graça. MA.S. and Coimbra. CN. 1998. The elaboration of indices to assess buological water quality. A case study. Water Res, 32: 380-392

Graça. MAS. Coimbra. C.N. and Santos, LM. 1995. Identification level and comparison of biological indicators in biomonitonng programs. Ciênc. Bıol. Ecol. Syst. (Portugal) 15:9-20.

Graça. MA.S., Ferreira, R.C.F, and Coimbra, C.N. 2001. Decomposition along a stream order gradient: the role of invertebrates and decomposers. J. N. Am. Benthol. Soc. (20:408-420).

Graça, M.A.S. Fonseca, D.M., and Castro, 5.T. 1989. The distribution of nacroinvertebrate communrties in two Portuguese rivers. Fresh. Biol. 22: 297-308

Hellawell, J.M. 1978. Biological surveillance of rivers: a biological monitoring handbook Water Researche Centre, Stevenage Laboratory. Elder Waig harts. SGI ITH U.K.

Hughes, B.D. 1978. The influence of factors other than pollution on the Shannon's diversity index for benthic macroinvertebrates in streams. Water Res 12:354-364.

Kolkowitz, R, and Marsson, M. 1908. Oekologie der pflanzhichen saprobien. Ber. Ot Botan Ges. 261: 505-519.

Kolkowitz. R, and Marsson, M. 1909. Oekologie der tierischen saprobien. Int. Rev. ges Hydrobiol, 2. $126-152$.

Krystiano, A.IA, and Kusjantono, H. 1991. A preliminary study of the use of BBI (Belgian Biotic Index) to assess the water quality of the river Ledok, Indonesia. Conservation and management of tropical inland waters. problems, solutions and perpectives. September 5.9. Hong Kong.

Malo, J. Morais, M. and Pinto, P. 1998. A contribution to the knowledge of the chironomid fauna (Diptera) in southern Portugal. Anna. Limnol. 34: 165-170.

Metcalfe. J.L 1989 Biological water quality assessment of running waters based on macroinvertebrate communities: history and present status in Europe. Environ. Pollut, 60: 101.139.

Metcalfe-Smith. J.L 1996. Biological water-quality assessment of nvers use of macroinvertebrate communities. In The rivers handbook. Edited by P. Calow and G.E. Petts. pp. 144-170.

Moreira. M.H., Canha, A.P. Franco, O.M., and Moura, A.M. 1988. Comunidades de macroinvertebrados do rio Caima e do curso supenor e médio do vouga: Cartografia da qualidade biológica da água. Rev. Biol. Aveiro 2:41-85.

Osborne. LL. Davies, RW. and Linton. K1. 1980. Use of hierarchical diversity indice in lotic community analysis. J. Appl. Ecol 17:567-580,

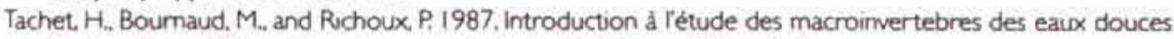
(systématque élémentaire et aperçu écologique), Université Lyon I, Lyon.

Vannote, RL. Minshall, G.W. Cummins, K.W. Sedell, J.R. and Cushing, C.E 1980 . The River Continuum concept Can. J. Fish, Aquat. So, 37: 130-137.

Washington. H.G, 1984. Diversity, buotic and similarty indices, A review with special relevance to aquatic ecosystems. Water Res, 18: 653-694. 

Série

Investigação

$\bullet$

Coimbra

Imprensa da Universidade

2002 